BRGÖ 2020

Beiträge zur Rechtsgeschichte Österreichs

Marta BARANOWSKA, Toruń

\title{
Proceedings of the Rhine Province Assembly in Karl Marx's articles as a source of knowledge about political and legal debates in the mid-nineteenth century
}

Research on the history of democracy and the rule of law also includes a history of debates on censorship and freedom of speech. The subject of the research paper is to analyze the issues raised by Karl Marx, who as a young journalist reported on the proceedings of the Sixth Rhine Province Assembly. In the articles published in the "Rheinische Zeitung" Marx touched upon several fundamental issues: criticism of censorship, especially the ban on publishing the Assembly proceedings, freedom of the press and press law. Interesting are also considerations about the status of the Rhine Province Assembly in the socio-political order. This research paper shows that Marx's articles published in the "Rheinische Zeitung" not only allow for getting to know his views, but also are a valuable source of historical knowledge about the political debates of those times.

Keywords: censorship - freedom of the press - Karl MARX - press law - Rheinische Zeitung,

\section{Introduction}

Research on the history of democracy and the rule of law also includes a history of debates on censorship and freedom of speech. The subject of the research paper is to analyze the issues raised by Karl Marx, who as a young journalist reported on the proceedings of the Sixth Rhine Province Assembly, which was held from 23 May to 25 July 1841 in Düsseldorf. ${ }^{1}$ It is worth

\footnotetext{
1 “In 1823, Prussia formed eight Assemblies of the estates. They embraced the heads of princely families, representatives of the knightly estate, the nobility, of towns and rural communities. The election system based on the principle of landownership provided for a majority of the nobility in the assemblies. The competency of the assemblies was restricted to questions of local economy and administration. They also had the right to express their desires on government bills submitted for discussion. They were largely powerless ("advisory") however, could only summoned
}

knowing his considerations, because he was undoubtedly one of the greatest political thinkers of the $19^{\text {th }}$ century, whose books were and are the subject of debates around the world. According to Étienne Balibar, "he was a philosopher of eternal beginning", that is why it is important to study his texts paying attention to the specificity of each stage of the formation of his worldview. ${ }^{2}$ In 1841 Marx joined the "Rheinische Zeitung für Politik, Handel und Gewerbe". This newspaper was first issued on 1 January 1842 with Moses Hess serving as edi-

[sic] by the Prussian government, and then they were held in secret. Furthermore, a two-thirds majority was required to pass resolutions. Since the knightly (aristocratic) estate held 278 of the 584 parliamentary votes (the towns estate had 182 and the rural estate 124), nothing could be done against its wishes". Marx/ Engels Internet Archive, Freedom of the Press 4.

${ }^{2}$ BALIBAR, Filozofia Marksa 11. 
tor. Marx was a chief editor from 15 October 1842 to 17 March $1843 .{ }^{3}$ Oscar J. Hammen wrote: "Although it is commonly claimed that the 'Rheinische Zeitung' adopted an increasingly revolutionary and democratic tone after Marx became the chief editor in the fall of 1842, actually he followed a disciplined editorial course that avoided any open declaration of principles". ${ }^{4}$ However, for the authorities, the published articles that criticized the government and postulated democratization were too radical. On 19 January 1843, the Prussian government issued a decree prohibiting the publication of the "Rheinische Zeitung" and from then on introducing particularly severe censorship. Newspaper publishers aimed to win the authorities' favour and to take a more moderate line. Marx disagreed and resigned from the editor's function on 31 March 1843. The "Rheinische Zeitung" was however terminated by Prussian state censorship two weeks later. ${ }^{5}$

Marx devoted three series of articles to the debates of the Sixth Rhine Province Assembly,

\footnotetext{
3 ,From the very outset of his career Marx created a profound impression on men like Moses Hess who saw him as a Voltaire, Rosseau, and Hegel blended into one person." MCGOVERN, Karl Marx 'First Political Writings 19.

${ }^{4}$ HAMMEN, Young Marx 111. "Marx showed his genius for tactics by advocating and later directing an editorial policy that criticised the existing government by indirection, interspersing the articles with praise of certain Prussian institutions without ever revealing the positive views of the newspaper. Late in August 1842, Marx warned Dagobert Oppenheim (connected with the management of the paper) against any ,clear demonstration against the foundations of the existing order' that would merely provoke a tightening of censorship, perhaps even the suppression of the paper." Ibid.

${ }^{5}$ Matthew Bunn wrote that "the assault on leftwing or 'Young' Hegelianism in 1842-1843 was the major censorship case of the decade. Banning the Deutsche Jahrbücher, Rheinische Zeitung, and Leipziger Allgemeine Zeitung was part of a significant, coordinated effort to undermine a small but a influential faction of radical social critics". BuNN, Censorship 375.
}

only the first and the third were published. The second series of articles "Debates on the Prussian Government and the Catholic Church" dealt with the conflict between church and state. The piece was banned by the censors and has never been found. In the third series of articles Marx published "Debates on the Law on the Theft of Wood". The first series of articles, "Proceedings of the Sixth Rhine Province Assembly. Debates on Freedom of the Press and Publication of the Proceedings of the Assembly of the Estates" appeared in issue No.125, on 5 May 1842. He discussed issues of freedom of the press, censorship and press law. He analyzed also the Assembly of the Estates as the institution of the representative system.

I would like to point out that Marx's articles published in the "Rheinische Zeitung" not only provide access to his views, but also are a valuable source of historical knowledge about the political debates of those times.

\section{Marx's Polemics with the Arguments of Opponents of the Freedom of the Press}

The starting point for Marx's consideration was the issue of the publication of the proceedings of the Assembly of the Estates. He criticized the views of the government newspaper "Preussische Staatszeitung", which supported political authority and censorship. The young Marx sarcastically criticized the arguments of this newspaper, but he pointed out that in the government's newspaper's petition one sentence is extremely apt: "The publication of the Assembly proceedings will only become a reality when they are treated as 'public facts', i.e., as subjectmatter for the press". ${ }^{6}$ Marx was convinced that

\footnotetext{
${ }^{6}$ MARX, Proceedings 10 ("Die Veröffentlichung der landständischen Verhandlungen wird erst eine Wahrheit, wenn dieselben als 'öffentliche Thatsachen`
} 
the full transparency of the proceedings of the Assembly was extremely important and he wanted to convince the readers of the "Rheinische Zeitung" to accept his beliefs. To this end, he quoted debates on the publication of the Assembly proceedings. As he wrote himself, he took a double role. As a historical spectator, he quoted the arguments of the representatives of the province. Thanks to that we have excellent source material regarding the deliberations and political views of those times. Marx, however, not only reported the debate, but also gave his own positive view of this question as a participant. He believed that it was justified to support one of the parties, because the defenders of press freedom were in the minority and "they have never come to know freedom of the press as a vital need. For them it is a matter of the head, in which the heart plays no part". ${ }^{7}$ It is worth emphasizing that Marx pointed to the importance not only of rational arguments, but also emotions. It is feelings that give people the greatest motivation to act. He wrote: "Goethe once said that the painter succeeds only with a type of feminine beauty which he has loved in at least one living being. Freedom of the press, too, has its beauty - if not exactly a feminine one which one must have loved to be able to defend it. If I truly love something, I feel that its existence is essential" ${ }^{8}$

behandelt, d.h. Gegenstand der Presse werden." MARX, EnGELS, Gesamtausgabe 125.)

${ }^{7}$ MARX, Proceedings 10 ("Sie haben die Freiheit der Presse nie als Bedürfniß kennen gelernt. Sie ist ihnen eine Sache des Kopfes, an der das Herz keinen Theil hat." MARX, ENGELS, Gesamtausgabe 125.)

${ }^{8}$ MARX, Proceedings 10 ("Göthe sagt einmal, dem Maler glückten nur solche weiblichen Schönheiten, deren Typus er wenigstens in irgend einem lebendigen Individuum geliebt habe. Auch die Preßfreiheit ist eine Schönheit - wenn auch grade keine weibliche - die man geliebt haben muß, um sie vertheidigen $\mathrm{zu}$ können. Was ich wahrhaft liebe, dessen Existenz empfinde ich als eine nothwendige." MARX, ENGELS, Gesamtausgabe 126.)
Marx in his articles polemized against the opponents of the freedom of the press, and showed the absurdity of their arguments. For example, they believed that the laws against freedom of the press were a refutation of freedom of the press. The existence of censorship justified its necessity. Once people were convinced that there should be censorship, it was the best solution now and forever. According to Marx, this is a "diplomatic" argument against all reform. Marx considered the illogical argument that censoring meant improving the press. To show the absurdity of this thesis, he asked the question: "Mirabeau - developed his talent in prison. Are prisons on that account schools of eloquence?"9 Marx pointed out: "The spiritual development of Germany has gone forward not owing to, but in spite of, the censorship". ${ }^{10}$

\section{Guarantees of freedom of the press: abolition of censorship and press law}

The condition for freedom of the press is the complete abolition of censorship. Marx in his first article "Comments on the Latest Prussian Censorship Instruction" criticized the Zensurinstruktion proclaimed by the Prussian government on 24 December $1841 .{ }^{11}$ Then, as the editor of the "Rheinische Zeitung", he was constantly dealing with censorship. In "Debates on Freedom of the Press" Marx put forward the thesis

\footnotetext{
${ }^{9}$ MARX, Proceedings 13 ("Mirabeau hat sich in Gefängnissen gebildet. Sind deswegen Gefängnisse die Hochschulen der Beredtsamkeit?" MARX, ENGELS, Gesamtausgabe 128.)

${ }^{10}$ MARX, Proceedings 13 ("Entwicklung Deutschlands ist nicht durch, sondern trotz der Censur vor sich gegangen. MARX, ENGELS, Gesamtausgabe 128.)

11 This article was first confiscated by the censor and then published in February 1843 in Switzerland in the collective work of "Anekdoten zur neuesten deutschen Philosophie und Publicistik, vol. 1".
} 
that the Zensurinstruktion is not a law, it is a police measure. He pointed out that censorship was preventive: texts intended for publication needed to be submitted to the censor for approval. ${ }^{12}$ Meanwhile, according to Marx, there are no preventive laws: law prevents only as a command. The law only becomes effective if it is infringed. "Laws are rather the positive, clear, universal norms in which freedom has acquired an impersonal, theoretical existence independent of the arbitrariness of the individual. A statute-book is a people's bible of freedom". ${ }^{13}$ This argument, published in an article on 12 May 1842 shows that he not only formulated his remarks about censorship as a journalist, but also as a lawyer. He criticized the Prussian censorship legislation of 1841 on the grounds not merely of its injustice but also of its illegality.

It should be noted that at the request of his father, Marx studied law in Bonn and then at the

12 "Since the Rheinische Zeitung was a morning paper, the copy had to be delivered to the censor in the evening. The editors would wait for the copy marked in red pencil to return and might work on the definitive newspaper into the wee hours. The Rheinische Zeitung wore out four censors over the course of its existence. Police commissioner Laurenz Dolleschall had a strange experience with Marx. Dolleschall had spent the entire evening waiting for the copy. He was impatient, as he planned to attend a ball. At his wits end, he took a coach to Marx's home. In response to his nervous ring at the door Marx opened an upstairs window and blandly reported that the next day's edition of the paper had been cancelled. During Dolleschall's term as a censor, protests from the editors to Regierungs-Präsident von Gerlach, Prussia's governor in the Rhineland, against articles rejected by the censor were regularly honoured. Of course these incidents compromised the prestige of the authorities". SANDERS, Prussian Censorship.

${ }^{13}$ MARX, Proceedings 31 ("Die Gesetze sind vielmehr die positiven, lichten, allgemeinen Normen, in denen die Freiheit ein unpersönliches, theoretisches, von der Willkühr des Einzelnen unabhängiges Dasein gewonnen hat. Ein Gesetzbuch ist die Freiheitsbibel eines Volkes." MARX, EnGELS, Gesamtausgabe 150.)
University of Berlin. ${ }^{14}$ According to Donald R. Kelly: "Too little attention has been paid to the profession first chosen by Marx, namely, that of the law. For centuries the law had been represented by its practitioners as the most direct path to the 'common good' (bonum publicum)". ${ }^{15}$ Kelly also pointed out that Marx did not distinguish between law and philosophy. "'Jurisprudence is the true philosophy' is a formula taken from the very first sentence of the Pandects, that seminal collection of classical jurisprudence which Marx had not only studied (with Savigny the previous year) but had even begun to translate into German". ${ }^{16}$

As an editor of the "Rheinische Zeitung", he had the opportunity to contribute to the 'common good', defending the freedom of the press. His arguments were both legal and philosophical. Marx was convinced that, "freedom is so much the essence of man that even its opponents implement it while combating its reality; they want

14 "Marx was declared 'diligent' and even 'very diligent and attentive' (sehr fleissig und aufmerksam) in all ten of the courses during 1835-36, six of which dealt with branches of law and legal history". After his transfer to the University of Berlin in the fall of 1836 "he studied 'Pandekten' with Savigny and ,Kriminalrecht' with Gans, and there is little doubt that their altercation had a shaping effect on Marx's own developing social views". Kelly, Metaphysics 351-352. For Marx`s student years in Berlin, see MILLER, SAWADZKI, Karl Marx in Berlin 35-115; CHRYSIS, 'True Democracy' 29-32.

${ }^{15}$ KeLly, Metaphysics 350.

${ }^{16}$ Ibid. "The justification for this identification had been two-fold: first, that law constituted a true 'science' (civilis scientia), since it was universal and viewed the world in terms of cause and effect, and, second, that unlike natural science it proposed as its principal object the common good of society. From the thirteenth century to Marx's own time the theme iurisprudentia est vera philosophia was pursued by jurists, commentators, and systematizers of law, including contributors to the French Civil Code of 1804. Whatever the relations between mature Marxism and classical 'civil science', the young Marx, at least the very young Marx, started in the old tradition". Ibid. 
to appropriate for, themselves as a most precious ornament what they have rejected as an ornament of human nature. No man combats freedom; at most he combats the freedom of others. Hence every kind of freedom has always existed, only at one time as a special privilege, at another as a universal right" ${ }^{17}$

Marx therefore stated that freedom is part of human nature, and true law is the one that makes natural human freedom the state law. According to Marx, freedom of the press always exists. Where there is censorship, freedom of the press exists, though not as a universal law, but as a privilege for the few, that is for the government and its supporters. Marx wrote: "The essence of the free press is the characterful, ration$\mathrm{al}$, moral essence of freedom. The character of the censored press is the characterless monster of unfreedom; it is a civilised monster, a perfumed abortion". ${ }^{18}$ When each text must be approved by the censor, then journalists and writers become secretaries of censors, who are omnipotent editors. In his first article, Marx criticized The Zensurinstruktion for its lack of precise rules and leaving great freedom to censors who could be guided by their subjective judgment. Marx wrote: "The writer, therefore, has fallen victim to the most frightful terrorism, and is subjected to the jurisdiction of suspicion. Laws

\footnotetext{
${ }^{17}$ MARX, Proceedings 26 ("Die Freiheit ist so sehr das Wesen des Menschen, daß sogar ihre Gegner sie realisiren, indem sie ihre Realität bekämpfen; daß sie als kostbarsten Schmuck sich aneignen wollen, was sie als Schmuck der menschlichen Natur verwarfen. Kein Mensch bekämpft die Freiheit; er bekämpft höchstens die Freiheit der andern. Jede Art der Freiheit hat daher immer existirt, nur einmal als besonderes Vorrecht, das andremal als allgemeines Recht." MARX, ENGELS, Gesamtausgabe 143.)

${ }^{18}$ MARX, Proceedings ("Das Wesen der freien Presse ist das charaktervolle, vernünftige, sittliche Wesen der Freiheit. Der Charakter der censirten Presse ist das charakterlose Unwesen der Unfreiheit, sie ist ein civilisirtes Ungeheuer, eine parfümirte Mißgeburt." MARX, ENGELS, Gesamtausgabe 146.)
}

against tendency, laws giving no objective standards, are laws of terrorism, such as were invented owing to the emergency needs of the state under Robespierre and the corruption of the state under the Roman emperors". ${ }^{19}$

Of course, such practices, that is, the creation of imprecise legal regulations and giving broad possibilities of their interpretation to officials, are an effective tool of power. Often these are special measures of the legislator, and not the result of incompetence in legislating. ${ }^{20}$ Slavoj Žižek made interesting observations about this type of practice, although in a different context, namely the functioning of totalitarian states. ${ }^{21}$ These states constitute very restrictive laws, so in the event of their strict enforcement, most citizens would end up as criminals, and therefore they are never fully applied. This measure, however, is intentional because the authorities can at the same time show their mercy and constantly use a very real threat to discipline society (for example, we could arrest you, but for now we will only book you - the effect of intimidation is achieved). Žižek gave the example of Art. 133 of the Criminal Code of former Yugoslavia, which stated that an author whose text could cause anxiety or dissatisfaction of its readers would be punished. The article did not specify the terms "anxiety" or "dissatisfaction" and it was possible to interpret them freely and thus provide by charges against political opponents. It was precisely on this type of practice of legislators striving for absolute power that Marx drew attention, pointing to the imprecise wording con-

\footnotetext{
${ }^{19}$ MARX, Prussian Censorship 15 ("Der Schriftsteller ist also dem furchtbarsten Terrorismus, der Jurisdiction des Verdachts anheim gefallen. Tenc/enzgesetze, Gesetze die keine objectiven Normen geben, sind Gesetze des Terrorismus, wie sie die Noth des Staats unter Robespierre und die Verdorbenheit des Staats unter den römischen Kaisern erfunden hat. MARX, ENGELS, Gesamtausgabe 107.)

${ }^{20}$ BARANOWSKA, Pierwsza walka 171-183.

21 ŽIŽEK, Przemoc 163.
} 
tained in the Zensurinstruktion and the possibility of its free interpretation by the censors.

Marx, referring to Hegel's philosophy, argued that censorship is contrary to the essence of state and law. It is a police measure against freedom, so it is not law, but lawlessness. Marx did not postulate the legal deregulation of the functioning of the press, but he considered the press law necessary. He wrote: „Laws are in no way repressive measures against freedom, any more than the law of gravity is a repressive measure against motion, because while, as the law of gravitation, it governs the eternal motions of the celestial bodies, as the law of falling it kills me if I violate it and want to dance in the air" ${ }^{22}$

\section{V: The Assembly of the Estates and the representative system}

Marx was convinced that the full transparency of the proceedings of the Assembly was extremely important and should be guaranteed by

\footnotetext{
${ }^{22}$ MARX, Proceedings 31. ("Gesetze sind keine Repressivmaßregeln gegen die Freiheit, so wenig wie das Gesetz der Schwere eine Repressivmaßregel gegen die Bewegung ist, weil es zwar als Gravitationsgesetz die ewigen Bewegungen der Weltkörper treibt, aber als Gesetz des Falls mich erschlägt, wenn ich es verletze und in der Luft tanzen will." MARX, ENGELS, Gesamtausgabe 150.) Padmaja Shaw believes that the arguments formulated by Marx are still valid, especially regarding the guarantee of the freedom of the press in a country like India. "Revisiting the free speech debate in the context of Marx's analysis makes it clear that it is necessary to ensure that independent constitutional authorities like the judiciary and the Election Commission are strengthened; strong press laws are enacted and enforced without curtailing freedom of the press; and censorship is challenged in all its forms, as it puts arbitrary power in the hands of the bureaucracy. The Indian experience also indicates that independent journalism that highlights the interests of the working class, despite the challenges it faces, can play a significant and historical role in politics of democratization and liberation". SHAW, Marx As Journalist 631.
}

law. It is a form of control of the Assembly, which is of great importance for the existence of a representative system. Formally, representatives of the province were to represent its interests in the Assembly, however, they formed an elite who actually cared only for themselves $^{23}$. Marx pointed out that they represented not provinces but the classes to which they belonged: princes, nobility, the bourgeoisie.

The Assembly's policy boiled down to the fact that it gave itself more and more powers and privileges that limited the rights of the province. "Thus the estates of the Middle Ages appropriated for themselves all the country's constitutional rights and turned them into privileges against the country. [...] In this way, the rights of the Provincial Assembly are no longer rights of the province, but rights against the province" ${ }^{24}$

Statements of representatives showed that they did not feel themselves to be representatives of the province. Marx perfectly captured this by citing the debate on the openness of the press. The representatives argued that the demand of the province to publish the reports on the debates was an unjustified pressure from 'outside'. The decision was supposed to belong solely to them. Marx commented: "It is truly the lan-

${ }^{23}$ "Wenn die Provinz verfassungsmässig Stände ernennt, um ihre allgemeine Intelligenz zu repräsentiren, so hat sie sich selbst eben damit alles eignen Urtheils und Verstandes völlig begeben, die nun einzig in den Auserwählten inkorporirt sind. Wie Sagen gehen, daß große Erfinder getödtet, oder, was keine Sage ist, lebendig auf Festungen vergraben wurden, sobald sie ihr Geheimniß dem Machthaber mitgetheilt, so stürzt sich die politische Vernunft der Provinz jedesmal in's eigne Schwerdt, sobald sie die große Erfindung der Landstände gemacht hat, allerdings um als Phönix für die folgenden Wahlen neu zu erstehen." MARX, ENGELS, Gesamtausgabe 138.)

${ }^{24}$ Marx, Proceedings 19 ("So hatten die Stände des Mittelalters alle Rechte des Landes in sich absorbirt und wendeten sie als Vorrechte gegen das Land. [...] Die Rechte des Landtags sind auf diese Weise nicht mehr Rechte der Provinz, sondern Rechte wider die Provinz." MARX, ENGELS, Gesamtausgabe 134.) 
guage of a ruler, which naturally has a pathetic flavour when coming from a modern baron. [...] Of course, the province has the right, under prescribed conditions, to create these gods for itself, but as soon as they are created, it must, like a fetish worshipper, forget that these gods are its own handiwork". ${ }^{25}$ The Assembly was treated as a "closed club" in which there were family-like relations. They did not want to allow the publication of the debates, because then they would be judged and held responsible by the provinces whose interests they had to represent. They wanted full autonomy, that is, more power. They also considered giving consent to the publication of reports, but on condition that they would censor their content. Marx criticized this idea. "A publication of the Assembly proceedings that depends on the arbitrary ruling of the Assembly of the Estates, however, is worse than none at all, for if the Assembly tells me not what it is in reality, but what it wants to seem to be in my eyes, I shall take it for what it gives itself out to be, for mere semblance, and things are bad when semblance has a legal existence". ${ }^{26}$

Marx concluded that representation that operates outside the represented knowledge is not a representation. He disagreed with the argument that such practices can be justified by the fact that parliamentary freedom was in its first peri-

\footnotetext{
${ }^{25}$ MARX, Proceedings 20 ("Es ist vollständige Herrschersprache, die allerdings im Munde eines modernen Standesherrn einen rührenden Beischmack hat. [...] Allerdings hat die Provinz das Recht, unter vorgeschriebenen Bedingungen, sich diese Götter zu machen, aber gleich nach der Schöpfung muß sie, wie der Fetischdiener vergessen, daß es Götter ihres Händewerks sind." MARX, EnGELS, Gesamtausgabe 135.) ${ }^{26}$ MARX, Proceedings 21 ("Eine Publikation der Landtagsverhandlungen aber, die der Willkühr der Landstände anheim gefallen ist, ist schlechter, als gar keine, denn wenn der Landtag mir giebt, nicht, was er ist, sondern was er für mich scheinen will, so nehme ich ihn als das, als was er sich giebt, als Schein und es ist schlimm, wenn der Schein gesetzliche Existenz hat." MARX, ENGELS, Gesamtausgabe 134.)
}

od of development. He also pointed out that opposition shows us the level of a political assembly, just as the opposition in general shows the level of development that a society has reached.

\section{Conclusion}

The main topic of the articles "Debates on Freedom of the Press" was the criticism of Prussian absolutism and censorship, especially the ban on publishing the Assembly proceedings. The articles provide an intriguing study into the history of press freedom debates.

Marx's goal is not simply the freedom of the press. "One form of freedom governs another just as one limb of the body does another. Whenever a particular freedom is put in question, freedom in general is put in question".27 Freedom is for Marx the most important value and essence of man. Reading Marx's first articles allows for getting to know the first stage of his work, which covered the period up to 1844/1845. The main topic of his deliberations was the formation of man, his creative potential and the category of alienation. For Marx the human essence is free original thinking and the need for expression, which is why freedom, including freedom of the press, is so important. According to Lotar Rosiński, the most significant motif of Marx's philosophy is his concept of criticism as "reform of consciousness". Thanks to critical thinking, a person can perceive the "illusion of understanding one's social situation".28 Marx always cut himself off from philosophy and theory; he wanted to change the world, not describe it. For this reason, he fought for the free-

\footnotetext{
${ }^{27}$ MARX, Proceedings 46 (“Jede Gestalt der Freiheit bedingt die andere, wie ein Glied des Körpers das andere. So oft eine bestimmte Freiheit in Frage gestellt ist, ist die Freiheit in Frage gestellt." MARX, ENGELS, Gesamtausgabe 168.)

${ }^{28}$ RASIŃSKI, Krytyka społeczna 95.
} 
dom of the press and, through it, he fought for the world to change.

Marx believed that freedom of the press was important for every person, but also for the wellbeing of society and the state. He wrote: "A country which, like ancient Athens, regards lickspittles, parasites and flatterers as exceptions to the good sense of the people, as fools among the people, is a country of independence and self-reliance. But a people which, like all peoples of the good old times, claims the right to think and utter the truth only for court-jesters, can only be a people without independence or personality". ${ }^{29}$

Marx emphasized the importance of the freedom to publish the Assembly's debates and the possibility of criticism of the authorities. Freedom of the press is the foundation of representative democracy. ${ }^{30}$ Nevertheless, the Assembly

${ }^{29}$ MARX, Proceedings 12 („Ein Land, welches wie das alte Athen, Speichellecker, Parasiten, Schmeichler als Ausnahmen von der Volksvernunft, als Volksnarren traktirt, ist das Land der Unabhängigkeit und Selbstständigkeit. Ein Volk, welches, wie alle Völker der besten Zeit, das Recht, die Wahrheit zu denken und auszusprechen, den Hofnarren vindicirt, kann nur ein Volk der Abhängigkeit und Selbstlosigkeit sein." MARX, ENGELS, Gesamtausgabe 126.)

${ }^{30}$ It is worth noting that in the countries of the Eastern Bloc, although all of Marx's works were published, his writings from the first period of creativity were omitted in the scientific and political discourse. Zdenék Mlynář (from 1946 a secretary of the Czechoslovak communist party, who supported "Prague spring" in 1968, so in 1969 he was removed from the party) wrote about it in the book „Mráz přichází z Kremlu”. Mlynář studied law at the University of Moscow, but only after returning to Czechoslovakia did he have the opportunity to learn about the writings of young Marx. "Marxism itself appeared to me suddenly in a different light than it was before due to the choice of Marxist literature at the Moscow State University. This choice was extensive [...] but it was nevertheless censored; Marx's works from the early period were missing, and there was no mention of Gramsci or Rosa Luxemburg". MLYNÁŘ, Mróz ze wschodu 34. He also described how, only after 1956, some of the communists with Stalinist views but "able to think", was only a dummy and not a real representative of the province. Cut off from society, they were unable to make just laws, which was one of the topics raised in the third series of articles, "Debates on the Law on the Theft of Wood". Marx, as a young man, perceived perfectly well the hypocrisy of the authorities and was indignant at it, particularly at the differences between their declarations and reality. At that time, Marx still believed that democracy could be introduced by democratic methods: rational arguments criticizing power and urging politicians to change their way of acting. That is why freedom of the press was so valuable to him as a tool for fighting for change. Reading Marx's press articles is necessary to capture the sense and purpose of his views. Marx initially had believed that the democratic methods could change the system and only the repression of the authorities prompted him to change his views on the means by which the actual realization of freedom would be possible.

\section{Correspondence:}

Prof. Dr. Marta BARANOWSKA

Nicolaus Copernicus University in Toruń

Faculty of Law and Administration

Ul. Władysława Bojarskiego 3

PL - 87-100 Toruń

mb1@law.umk.pl

ORCID-Nr.: 0000-0002-0365-1023 studying Marx's works, began to discover that many of his thoughts were in a fundamental contradiction with the interpretation of Marxism by party members. They were aware of Marx's humanism, whose philosophy focused on the issues of human freedom and emancipation, and class struggle was only a means to achieve these goals. Mlynár stressed, however, that he saw both the similarities and differences between Marx's writings and the official communist ideology. 


\section{Bibliography:}

Étienne BALIBAR, Filozofia Marksa (Warszawa 2007).

Marta BARANOWSKA, Pierwsza walka Karola Marksa, czyli Uwagi dotyczące nowej instrukcji o cenzurze, in: Przegląd Filozoficzny. Nowa Seria 4 (2018) 171-183.

Matthew BunN, "Censorship is Official Critique”. Contesting the Limits of Scholarship in the Censorship of the Hallische Jahrbücher, in: Central European History 47 (2014) 375-401.

Alexandros CHrysis, 'True Democracy' as a Prelude to Communism. The Marx of Democracy (Cham 2018).

Oscar J. HAMMEN, The Young Marx. Reconsidered, in: Journal of the History of Ideas 31/1 (1970) 109-120 (28. 6. 2019).

Hanno HARDT, Communication is Freedom: Karl Marx on Press Freedom and Censorship, in: Javnost / The Public 7 (2000) 85-99.

Donald R. KelLy, The Metaphysics of Law. An Essay on the Very Young Marx, in: The American Historical Review 83 (1978) 350-367.

Karl MARX, Comments on the Latest Prussian Censorship Instruction, in: Marx/Engels Internet Archive, [https://www.marxists.org/archive/marx/works/18 42/02/10.htm] (1988 / 6. 6. 2019).

IDEM, Proceedings of the Sixth Rhine Province Assembly. Debates on Freedom of the Press and Publication of the Proceedings of the Assembly of the Estates, in: Marx/Engels Internet Archive [http://www.marxists.org/archive/marx/works/184 0/free-press/index.htm] (23. 8. 2000 / 15. 6. 2019).

Marx/Engels Internet Archive, On Freedom of the Press. General Introduction [https://www.marxists.org/archive/marx/works/d ownload/Marx_Rheinishe_Zeitung.pdf] (23. 8. 2000 / 15. 6. 2019).

Karl MARX, Friedrich ENGELS, Gesamtausgabe (MEGA). Erste Abteilung: Werke - Artikel - Entwürfe, Bd. 1 (Berlin 1975).

Arthur F. MCGOVERN, Karl Marx' First Political Writings: The Rheinische Zeitung, 1842-1843, in: Frederick J. ADELMANN, Demythologizing Marxism. A Series of Studies on Marxism (Dordrecht 1969) 19-63.

Horst Mewes, On the Concept of Politics in the Early Work of Karl Marx, in: Social Research 43 (1976) 276-294.

Sepp Miller, Bruno SAWAdZKI, Karl Marx in Berlin (Berlin 1956).

Zdenek MLYNÁ̌̌, Mróz ze wschodu (Warszawa 1989).

Lotar RASIŃSKI, Krytyka społeczna jako „reforma świadomości”. próba reinterpretacji Marksowskiego projektu krytyki, in: Paweł RUDNICKI, Marcin STARNAWSKI, Mirosława NOWAKDZIEMIANOWICZ (eds.), Władza, sens, działanie. studia wokół związków ideologii i edukacji (Wrocław 2012) 93-105.

Huub SANDERS, Prussian censorship and Karl Marx's brief career as an editor for the „Rheinische Zeitung", in: International Institute of Social History [http://www.iisg.nl/collections/rheinischezeitung/ history.php] (3. 4. 2009 / 1. 7. 2019).

Padmaja SHAW, Marx As Journalist. Revisiting The Free Speech Debate, in: Triple C. Cognition. Communication. Co-operation 10 (2012) 618-632.

Slavoj ŽIŽEK, Przemoc. Sześć spojrzeń z ukosa (Warszawa 2010). 